\title{
Biohydrogen Production from Co-Digestion of High Carbohydrate Containing Food Waste and Combined Primary and Secondary Sewage Sludge
}

\author{
MARYAM ARAIN*, RASOOL BUX MAHAR**, AND ABDUL RAZAQUE SAHITO* \\ RECEIVED ON 07.10.2016 ACCEPTED ON 29.05.2017
}

\begin{abstract}
In this paper, FW (Food Waste) and SS (Sewage Sludge) were co-digested for biohydrogen production. After characterization both FW and SS were found as better option forbiohydrogen production. FW was rich in carbohydrate containing specially rice, which was added as more than $50 \%$ and easily hydrolyzable waste. FW is considered as an auxiliary substrate for biohydrogen production and high availability of carbohydrate in FW makes it an important substrate for the production of biohydrogen. On the contrary, SS was rich in protein and has a high pH buffering capacity, which makes it appropriate for codigestion. Adequate supplementation of inorganic salts, the addition of hydrogen producing inoculums, protein enrichment and pH buffering capacity of SS and carbohydrate content in FW increases the hydrogen production potential. Various experiments were performed by considering different mixing ratios like 90:10, 80:20, 70:30, 60:40 and 50:50 of FW and SS. The 50:50 and 90:10 mixing ratio of FW and SS were found as best among all other co-digested ratios. The maximum specific hydrogenyield $106.7 \mathrm{~mL} / \mathrm{gVS}_{\text {added }}$ was obtained at a waste composition of $50: 50$ followed by $92.35 \mathrm{~mL} / \mathrm{gVS}_{\text {added }}$ from 90:10 of FW to SS. The optimum pH and temperature for operating this process werein the range of 5.5-6.5 and $35^{\circ} \mathrm{C}$. The production of clean energy and waste utilization in anaerobic co-digestion process makes biohydrogen generation a promising and novel approach to fulfilling the increasing energy needs as a substitute for fossil fuels.
\end{abstract}

Key Words: Biohydrogen, Food Waste, Sewage Sludge, Volatile Solids.

\section{INTRODUCTION}

$\mathrm{F}$ ossil fuels are nonrenewable sources of energy andcausepollution. The quantity of fossil fuels is limited, thus they should be substituted with renewable energy sources which are nonpolluting sources of energy [1]. Hydrogen is used as an alternative to fossil fuelsthatcan be used in place of various kinds of fossil fuels [2]. Environmental impacts and cost of fossil fuels in recent years have developed an interest in sustainable, renewable and clean energy alternatives [3]. Hydrogen is a sustainable and clean fuel and has a very high energy yield of $122 \mathrm{~kJ} / \mathrm{g}$. Such a high yield makes it energy carrier of the future, and also viable alternative to

Corresponding Author (E-Mail: ms.maryam@faculty.muet.edu.pk)

* Institute of Environmental Engineering \& Management, Mehran University of Engineering \& Technology, Jamshoro.

** US-Pakistan Centres for Advanced Studies in Water, Mehran University of Engineering \& Technology, Jamshoro.

Mehran University Research Journal of Engineering \& Technology, Volume 37, No. 1, January, 2018 [p-ISSN: 0254-7821, e-ISSN: 2413-7219] 
fossil fuel. Hydrogen is not only utilized as a source of energy butalso used as a feedstock in the production of chemicals, steel processing,hydrogenation of oil and fats, reformulation and desulfurization of gasoline in refineries and for the production of electronic devices. In recent years significant attention has been gained by efficient and cost effective hydrogen production technologies as a need for hydrogen energy is increasing [4]. Conventional hydrogen production methods are not cost-effective because they require high energy like steam reforming of hydrocarbons, electrolysis of water and non-catalytic partial oxidation of fossil fuels [5]. Due to the current oil crisis and pollution causing effects of nonrenewable energy sources advancement in renewable and ecofriendly energy technologies have been increased [6]

Among all renewable and inexhaustible technologies anaerobic co-digestion of renewable fuel sources like waste plays major role in the production of clean energy and also in the treatment of waste that on the other way would be contributing to global environmental problems [7-9]. Biohydrogen production by using waste as raw material has been considering attention as a sustainable and eco-friendly process that does not require fossil fuel [10]. Productions of hydrogen through biological processes have more advantages than chemical methods [9]. Biohydrogen production has been considered as clean, renewable and environmentally friendly technique. Biohydrogen is produced biologically by bacteria and algae [11-13]. Biohydrogen can also be produced through biomass with either butyrate or acetate or both [14].

Biological methods of hydrogen production are divided into two categories. The first is by anaerobic bacteria and other is by photosynthetic bacteria [10]. The types of bacteria involved in biohydrogen production are Escheria coli, Enterobacter and Clostridium [15-16]. These hydrogen producing bacteria widely found in wastewater sludge, soil, sediments manure and compost [17]. In photosynthetic process, algae utilize water and carbon dioxide in the production of hydrogen and in fermentation process anaerobic bacteria consume organic acids like acetic, butyric and lactic acid for the production of hydrogen [9]. In the fermentative process of biohydrogen production, organic wastes may become less expensive and abundant source; in which stabilization and reduction of organic waste take place [8]. Co-digestion of FW with sewage sludge produces biohydrogen because FW and SS were known as necessary and auxiliary substrate for hydrogen production. Some experimental results were reported using food waste [13,18-20], waste activated sludge [21-22], municipal solid waste [18,2325]. FW is suitable for the production of hydrogen as it is rich in carbohydrate and hydrolyzable waste [26].

An important part is that it is an easily degradable waste with high potential of biogas production [27]. Although this waste is also a major source of vermin attraction, ground water contamination, gaseous emissions and odor emanation due to high organic content. FW is carbohydrate rich waste and SS is rich in protein [28]. Protein enrichment by mixing SS enhances the potential of hydrogen production. For effective hydrogen production appropriate amount of minerals and $\mathrm{pH}$ buffer solution are used to maintain the nutrient balance and required $\mathrm{pH}$ [29]. A previous study indicates that addition of SS with food provides a balanced carbohydrate/protein ratio [30]. Co-digestion of carbohydrate rich waste with SS is not only suitable for the treatment of waste but also energy intensive. This concept of anaerobic co-digestion of SS and FW for biohydrogen production is provided to be significant, as it also contribute to the management of solid waste [28].

From the literature it was conceived that the previous studies work was carried on the substrate having low carbohydrate whereas present study was aimed to produce hydrogen by anaerobic co-digestion of high 
carbohydrate containing FW and SS.In this study, the substrate was characterized and co-digested in the batch type cultivation system under various mixing ratios to produce hydrogen and find out the best mixing ratio for co-digestion of high carbohydrate containingFW and combined primary and secondary sludge on the basis of VS (Volatile Solids) added into the reactors.

\section{METHODOLOGY}

\section{$2.1 \quad$ Materials}

Materials used for biohydrogen production are FW, primary sludge and secondary sludge (waste activated sludge) [29]. These wastes are complimentary for biological hydrogen production. FW collected from dining hall contains a variety of beans and vegetables like rice, wheat bran, potatoes, pulse, cabbage, beans and peas [18-19,23,29]. The maximum content of carbohydrates makes FW an auxiliary feedstock for the production of biohydrogen. Biohydrogen was produced by Lay et. al. [25] fromthe OFMSW (Organic Fraction of Municipal Solid Waste). Kim et. al. [28] produced hydrogen by using FW as the main substrate. Shin [31] produced hydrogen from FW under thermophilic conditions, Ginkel et. al. [32] produced biohydrogen from food processing industrial wastewater effluent, and Tanisho et. al. [33]produced hydrogen from molasses.

Primary sludge was collected from the sewer main hole. SS is also rich in protein and polysaccharides and hydrogen yield were reported by Wang et. al. [21-22, 34]. The microorganisms responsible for fermentative reaction include the members of Clostridium, many of them are found in SS [35]. Additionally, effluent from the hydrogen reactor can be used as a feedstock for photo fermentative biohydrogen production from SS [36]. Waste activated sludge was taken from anaerobic digester. The Volatile suspended solids, alkalinity and $\mathrm{pH}$ of activated sludge were $6.5 \mathrm{~g} / \mathrm{L}, 3.23 \mathrm{~g} \mathrm{CaCO}_{3} / \mathrm{L}$ and 7.2, respectively. This sludge was digested and enriched with bacterial growth. The study is limited to the FW having high carbohydrate containing specially rice, which was added as more than $50 \%$ and was acidic in nature with the cumulative moisture content of $80-84 \%$. The SS used in the present study having only 3\% of TS (Total Solids) and was neutral in the nature. Moreover, the co-digestion was carried out at mesophilic temperature range of $35^{\circ} \mathrm{C}$.

\subsubsection{Preparation of Substrate}

The substrate was prepared by using FW, primary Sludge and waste activated sludge. FWan aerobically crushed by blender and the slurry was prepared by mixing the blended FW with distilled water. For the preparation of slurry $10 \mathrm{ml}$ distilled water was added in one gram of FW sample [29]. The digested sludge taken from anaerobic digester was heated for 15 minutes at $90^{\circ} \mathrm{C}$ for harvesting hydrogen producing bacteria [14]. Then all substrate including waste activated sludge, primary sludge and FW were filtered through stainless steel sieve of Mesh No.8 with sieve opening size of $2.68 \mathrm{~mm}$.

\subsubsection{Preparation of Hydrogen Producing Inoculum}

The inoculum was prepared using a sucrose medium as substrate and digested sludge as a source of organisms [17]. The medium contains inorganic salts, phosphate buffer and $10 \mathrm{~g} / \mathrm{L}$ sucrose. Cellulose powder can also be used as substrate for hydrogen production [10], the maximum hydrogen yield obtained was $102 \mathrm{~mL} / \mathrm{g}$ cellulose [37] and 2.18mol/g cellulose [38]. Hydrogen production from sucrose has been widely used due to high potential of hydrogen production like $4.52 \mathrm{~mol}$ of Hydrogen $/ \mathrm{mol}$ sucrose [39], 3.47mol of Hydrogen/mol sucrose [40] and $1.5 \mathrm{~mol}$ of Hydrogen/mol sucrose [41], and the yield from glucose was only $0.91 \mathrm{~mol} / \mathrm{mol}$ glucose [32]. Inorganic

Mehran University Research Journal of Engineering \& Technology, Volume 37, No. 1, January, 2018 [p-ISSN: 0254-7821, e-ISSN: 2413-7219] 
salts in medium are $3.2 \mathrm{~g} / \mathrm{L} \mathrm{Na}_{2} \mathrm{HPO}_{4} \cdot 7 \mathrm{H}_{2} 0,1.5 \mathrm{~g} / \mathrm{L}$ $\mathrm{KH}_{2} \mathrm{PO}_{4}, 4.2 \mathrm{~g} / \mathrm{L} \mathrm{NH}_{4} \mathrm{CL}, 0.18 \mathrm{~g} / \mathrm{L} \mathrm{MgCl}_{2} \cdot 4 \mathrm{H}_{2} \mathrm{O}$ [10]. The 20 $\mathrm{mL}$ digested sludge and $80 \mathrm{~mL}$ sucrose medium were added in the reactor.Before the bottle was capped the head space of the reactor bottle was flushed with nitrogen gas for one minute.

\subsubsection{Preparation of Gas Measuring Jars}

The reactors are connected to gas measuring jar which were filled with the $3 \mathrm{MNaOH}$ solution and thymolphthalein indicator. The $3 \mathrm{MNaOH}$ solution was prepared by dissolving $120 \mathrm{~g}$ of $\mathrm{NaOH}$ in oneliter of distilled water. The thymolphthaleinindicator was prepared byadding $20 \mathrm{mg}$ of thymolphthalein indicator powder in $45 \mathrm{ml}$ ethanol.

\subsubsection{Operating Procedure for Batch Reactors}

The tests were conducted using $500 \mathrm{~mL}$ glass reactor bottles. Total five bottles with different volumetric ratios of FW and SS were added according to achieve a final volume of $200 \mathrm{~mL}$ in each reactor as shown in Fig. 1. Five ratios were made and the mixing ratio of FW and SS in each reactor was designed accordingly as given in Table 1.

All reactor bottles were inoculated with hydrogen producing inoculum and are supplemented with chemicals [25]. The $20 \mathrm{ml}$ hydrogen producing inoculum, appropriate amount of substrate which were designed accordingly and varying amount of phosphate buffer solution was added to each reactor bottle. The buffer solution was prepared by using 1liter distilled water $0.2 \mathrm{~g} \mathrm{KCl,} 8 \mathrm{~g}$ $\mathrm{NaCl}, 4.4 \mathrm{~g} \mathrm{Na}_{2} \mathrm{HPO}_{4}, 0.24 \mathrm{~g} \mathrm{KH}_{2} \mathrm{PO}_{4}$. The inorganic salts along with their quantity are given in Table 2. Then all reactors were purged with $\mathrm{N}_{2}$ for one minute and capped tightly. The Gas produced anaerobically in all reactor bottles and was collected in the gas measuring acrylic glass jar. The produced gas was a mixture of $\mathrm{CO}_{2}$ and $\mathrm{H}_{2}$ and for the separation of hydrogen from the mixture of gases $3 \mathrm{MNaOH}$ solution was used in the gas measuring jar.

\subsubsection{Gas Sample Analysis}

For measuring the quantity of gas produced, the water displacement technique was used. The gas was transferred with the help of pipe to the gas collection jar containing $\mathrm{NaOH}$ solution in it, the quantity of $\mathrm{NaOH}$ solution was displaced by the produced gas. Hence, the quantity of $\mathrm{NaOH}$ solution in the inner tube is equal to the quantity of biohydrogen produced. Volume of gas produced in $\mathrm{mL}$ was calculated by using Equation (1).

$V=\frac{\pi}{4} d^{2}(h+H)$

Where, $\mathrm{V}$ is the volume of hydrogen in $\mathrm{ml}$, $\mathrm{d}$ is the diameter of the inner tube of the gas measuring jar in $\mathrm{cm}, \mathrm{h}$ is the height of the $\mathrm{NaOH}$ solution raised in the inner tube and the $\mathrm{H}$ is the height of the $\mathrm{NaOH}$ solution raised in the outer tube of the gas jar. The measured volume of the hydrogen gas was converted into the standard pressure and temperature by using Equation (2).

$V_{S T P}=V \times \frac{P}{101.325} \times \frac{273}{273+T}$

Where $\mathrm{V}_{\text {STP }}$ is the volume of hydrogen in $\mathrm{mL}$ at standard temperature and pressure, $\mathrm{V}$ is the volume of hydrogen in $\mathrm{ml}, \mathrm{P}$ is the atmospheric pressure and $\mathrm{T}$ is the temperature of the gas measuring jar.

The glass syringe was used for collecting the gas sample [42]. Hydrogen content was determined by gas chromatography (Shimadzu AOC-20i) using a thermal conductivity detector and columnRt-Q-BOND (30 m length, $0.53 \mathrm{~mm}$ ID and 20 $\mathrm{mm} \mathrm{df}$ ) with nitrogen as the carrier gas at a pressure of 30 psi in the column operated with 
column temperature of $50^{\circ} \mathrm{C}$ injector and detector temperature was $80^{\circ} \mathrm{C}$, respectively. The Senso direct 150 multi-meterinstrument was used to monitor the $\mathrm{pH}$ of the sample.TSs, VSs, Alkalinity, COD (Chemical Oxygen Demand) and $\mathrm{NH}_{3}-\mathrm{N}$ were determined by following APHA standards [43].

\section{RESULTS AND DISCUSSION}

\subsection{Characteristics of Food Waste and Sewage Sludge}

The characteristics of substrate are given in Table $\mathbf{3}$. The FW contains alkalinity as low as $40 \mathrm{mg} / \mathrm{L}$ as $\mathrm{CaCO}_{3}$ while alkalinity contains in SS was high $1550 \mathrm{mg} / \mathrm{L}$ as $\mathrm{CaCO}_{3}$, which shows that it allowed fermentation to establish $\mathrm{pH}$ 5.5-6.0 that is conductive for biohydrogen production

[29]. The pH values of SS and FW were 7 and 6.2. All reactor bottles were adjusted to initial pH 7 [29]. As the FW fraction of the substrate increases the decline in $\mathrm{pH}$ increased, for that phosphate buffer solution were added to reactor bottles and least decline was observed in reactors where sludge fraction is more in the substrate.The concentration of COD in FW and SS was

TABLE 2. THE QUANTITY OF CHEMICAL USED AS SUPPLEMENT IN ALL BIOHYDROGEN REACTORS

\begin{tabular}{|c|c|c|}
\hline No. & Chemical Formula & Quantity Added (mg) \\
\hline 1. & CaCl2.2H2O & 2 \\
\hline 2. & Na2MoO4.4H2O & 2 \\
\hline 3. & MgCl2.4H2O & 4 \\
\hline 4. & MnCl2.6H2O & 4 \\
\hline 5. & FeCl2.4H2O & 10 \\
\hline 6. & KH2PO4 & 200 \\
\hline
\end{tabular}

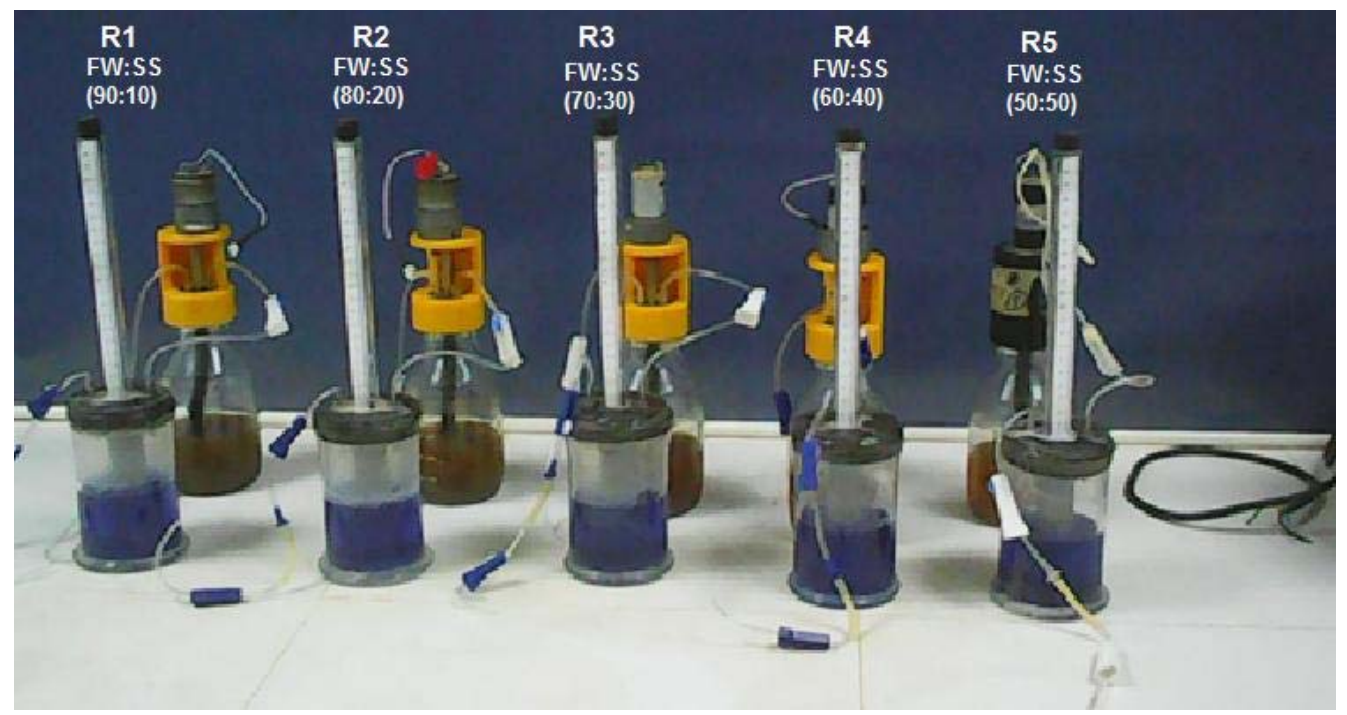

FIG. 1. REACTOR BOTTLES OF VARIOUS RATIOS OF FOOD WASTE AND SEWAGE SLUDGE ALONG WITH GAS MEASURING JARS

TABLE 1. MIXING RATIOS OF FOOD WASTE AND SEWAGE SLUDGE IN TERMS OF PERCENTAGE AND VOLUME

\begin{tabular}{|c|c|c|c|c|}
\hline Name of Reactor & Food Waste (\%) & Sewage Sludge (\%) & Food Waste (mL) & Sewage Sludge (mL) \\
\hline 1 & 90 & 10 & 180 & 20 \\
\hline 2 & 80 & 20 & 160 & 40 \\
\hline 3 & 70 & 30 & 140 & 60 \\
\hline 4 & 60 & 40 & 120 & 80 \\
\hline 5 & 50 & 50 & 100 & 100 \\
\hline
\end{tabular}

Mehran University Research Journal of Engineering \& Technology, Volume 37, No. 1, January, 2018 [p-ISSN: 0254-7821, e-ISSN: 2413-7219] 
28000 and 15000mg/L, respectively and previous study has reported that the majority of the volatile fraction of the SS is proteineous materials and proteineous COD is more than $50 \%$ of the total COD in the SS [28]. The result indicates that FW contains high concentration of carbohydrate, which suggests the availability of FW as suitable and auxiliary substrate for hydrogen production $[28,31-33]$.

Both substrates contain significant concentrations of ammonia nitrogen as $1322 \mathrm{mg} / \mathrm{L}$ in SS and $605 \mathrm{mg} / \mathrm{L}$ in FW. This high concentration of ammonia nitrogen in SS suggests that SS hasa high concentration of protein in it[29], and addition of SS with food provides a balanced carbohydrate/protein ratio [30].The FW contains TS and VS concentration as 16120 and $15650 \mathrm{mg} / \mathrm{L}$, respectively. Although, TS and VS in SS were 29500and 11500 mg/L, respectively. Moreover, VS in SSindicate high organic matter as compared to FW.

The VFA in FW were 2040 mg/L shows that acid genesis phase has started while in SS no VFA were detected. Moisture content in FW and SS indicates that the rapid gas generation will take place due to easy and rapid degradation of co-substrate. The $\mathrm{pH}$ buffering capacity and protein enrichment of SS with FW which contains complimentary nutrient composition, suggests the appropriate potential of co-digestion for maximum hydrogen production.

\subsection{Co-Digestion of Food Waste and Sewage Sludge}

FW and SS both are the appropriate sources for the biological production of hydrogen. Availability of carbohydrates in carbon rich FW, Protein enrichment and $\mathrm{pH}$ buffering capacity of SS and supplementation of inorganic salts enhance the hydrogen production potential.

In fermentation process $\mathrm{pH}$ influence the metabolic pathway for the conversion of carbohydrate and for the production of hydrogen. Although, in each reactor the initial $\mathrm{pH}$ was maintained as 7 and final $\mathrm{pH}$ varied from 3.8-6.5. The sludge fraction of feedstock has least decline in $\mathrm{pH}$ due to $\mathrm{pH}$ buffering capacity and a decline in $\mathrm{pH}$ increases as the FW fraction of the feedstock increased [29]. This pH lowering of FW also inhibits methanogenic activity.Previous studies reported that the suitable $\mathrm{pH}$ for the biological production of hydrogen from anaerobic co-digestion of FW and SS was in the range of 5.5-6.0 [29].For maintaining the required $\mathrm{pH}$ in all reactor bottles adequate amount of $\mathrm{pH}$ buffer solution were added. SS has higher alkalinity as compared with FW and therefore has more $\mathrm{pH}$ buffering capacity [29,30]. This pH buffering capacity of SS was useful for the co-digestion of waste in mixture.

TABLE 3. CHARACTERISTICS OF SUBSTRATES

\begin{tabular}{|c|c|c|}
\hline Parameter & Food Waste & Sewage Sludge \\
\hline Alkalinity (mg CaCO3/L) & 40 & 7550 \\
\hline $\mathrm{pH}$ & 6.2 & 15000 \\
\hline COD (mg/L) & 28000 & 1322 \\
\hline NH3-N (mg/L) & 605 & 29500 \\
\hline Total Solids (mg/L) & 16120 & 11500 \\
\hline Volatile Solids (mg/L) & 15650 & 0 \\
\hline Volatile Fatty Acids (mg/L CH3COOH) & 2040 & 97.05 \\
\hline Moisture Content (\%) & 83.88 & \\
\hline
\end{tabular}

Mehran University Research Journal of Engineering \& Technology, Volume 37, No. 1, January, 2018 [p-ISSN: 0254-7821, e-ISSN: 2413-7219] 
In Reactor-1, the $180 \mathrm{~mL}$ of FW was mixed with $20 \mathrm{~mL}$ of $\mathrm{SS}$. Initial $\mathrm{pH}$ was maintained at 7 while the final value varied. Due to the maximum content of carbohydrate in FW the hydrogen yield from this mixture was $92.35 \mathrm{~mL} / \mathrm{g}$ VS. Based on the availability of carbohydrates from FW in Reactor-1, the volumetric ratio 90:10 produces maximum hydrogen and results of this mixture are in agreement to the Kim et. al. [28].

In the study presented, the maximum specific hydrogen was observed as $106.74 \mathrm{~mL} / \mathrm{gVS}_{\text {added }}$ from the volumetric ratio of 50:50. Initial $\mathrm{pH}$ was maintained at 7 and final $\mathrm{pH}$ was 6.5 of this 50:50 mixture of FW and SS. This mixing ratio has maximum hydrogen production due to carbohydrate content in FW, protein enrichment and $\mathrm{pH}$ buffering capacity of SS which was added here $100 \mathrm{~mL}$. The factor impacting hydrogen production is the availability of carbohydrate, $\mathrm{pH}$ and protein. This 50:50 mixing ratio was found as best among all other codigestion ratio, in which carbon rich FW was added with SS that favored the conditions for maximum hydrogen production by influencing the metabolic conversion of carbohydrate for the formation of biohydrogen. The results of the present study are in comparison to the results of Zhu et.al. [29]. According to Zhu et. al. [29] the hydrogen yield of $104 \mathrm{~mL} / \mathrm{gVS}_{\text {added }}$ and $112 \mathrm{~mL} / \mathrm{gVS}_{\text {added }}$ were producedat a volumetric ratio of $3: 1$ and 1:1 of FW to SS.

In the Reactor-2, the volumetric ratio 80:20 was prepared by using $160 \mathrm{~mL} \mathrm{FW}$ with $40 \mathrm{~mL}$ of SS. In this mixture the final $\mathrm{pH}$ was 4 and gas production was $81.95 \mathrm{~mL} / \mathrm{g} \mathrm{VS}_{\text {added }}$. In the Reactor-3, the $140 \mathrm{~mL}$ of FW was mixed with $60 \mathrm{~mL}$ of SS and mixing ratio 70:30 was prepared. Initial pH was adjusted to 7 and final $\mathrm{pH}$ was 4.2. Due to lower final $\mathrm{pH}$ value, the availability of suitable substrate was limited in the reactor. Thus, the mixture generate hydrogen of only $76.80 \mathrm{~mL} / \mathrm{gVS}_{\text {added }}$. The mixing ratio 60:40 which contains $120 \mathrm{~mL} \mathrm{FW}$ and $80 \mathrm{~mL}$ SS was initially adjusted at pH 7 and final $\mathrm{pH}$ of this mixture was observed 5.5. Due to the high $\mathrm{pH}$ buffering capacity of SS which was added here $80 \mathrm{~mL}$ the specific hydrogen yield $82.91 \mathrm{~mL}$ was obtained at this mixing ratio.

The results of these mixing ratios and hydrogen yield indicates that gas was produced in each reactor at all mixing ratios, but highest yields from this study 106.74

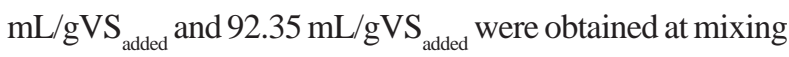
ratio 50:50 and 90:10 of FW to SS. The 50:50 mixing ratio has most hydrogen production potential and this was substantially due to the suitable $\mathrm{pH}$ value and the presence of carbohydrate from FW. The cumulative hydrogen production obtained from all reactors at different ratios of FW to SS isshown in Fig. 2. The maximum hydrogen production $289.8 \mathrm{~mL}$ observed from $\mathrm{FW}$ to SS ratio of 50:50, followed by 281.4, 242.9, and 221,232 from the ratios of $90: 10,80: 20,70: 30$, and 60:40, respectively.

Flow rates of hydrogen from all mixing ratios are given in Fig. 3. Hydrogen production was analyzed on a daily basis for five days. Hydrogen production was started from day one and maximum hydrogen was observed at day one and then it was gradually decreased on subsequent days due to decline in $\mathrm{pH}$ and microbial conversion of organic compounds into hydrogen.

TABLE 4. SPECIFIC HYDROGEN PRODUCTION PER GRAM OF VS ADDED $_{\text {}}$

\begin{tabular}{|c|c|c|c|}
\hline Name of Reactor & VSadded (mg VS) & H2 (mL) & Specific H2 (mL/gVSadded) \\
\hline 1 & 304.7 & 281.4 & 92.35 \\
\hline 2 & 296.4 & 242.9 & 81.95 \\
\hline 3 & 288.1 & 221 & 76.70 \\
\hline 4 & 279.8 & 232 & 82.91 \\
\hline 5 & 271.5 & 289.8 & 106.74 \\
\hline
\end{tabular}

Mehran University Research Journal of Engineering \& Technology, Volume 37, No. 1, January, 2018 [p-ISSN: 0254-7821, e-ISSN: 2413-7219] 


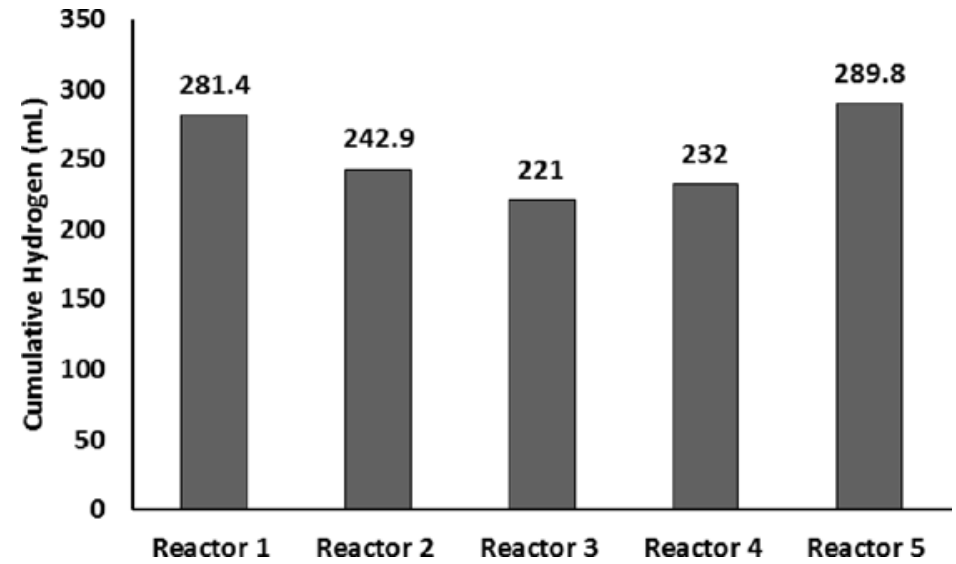

FIG. 2.CUMULATIVEBIOHYDROGEN PRODUCTION FROM DIFFERENT RATIOS OF FW AND SS

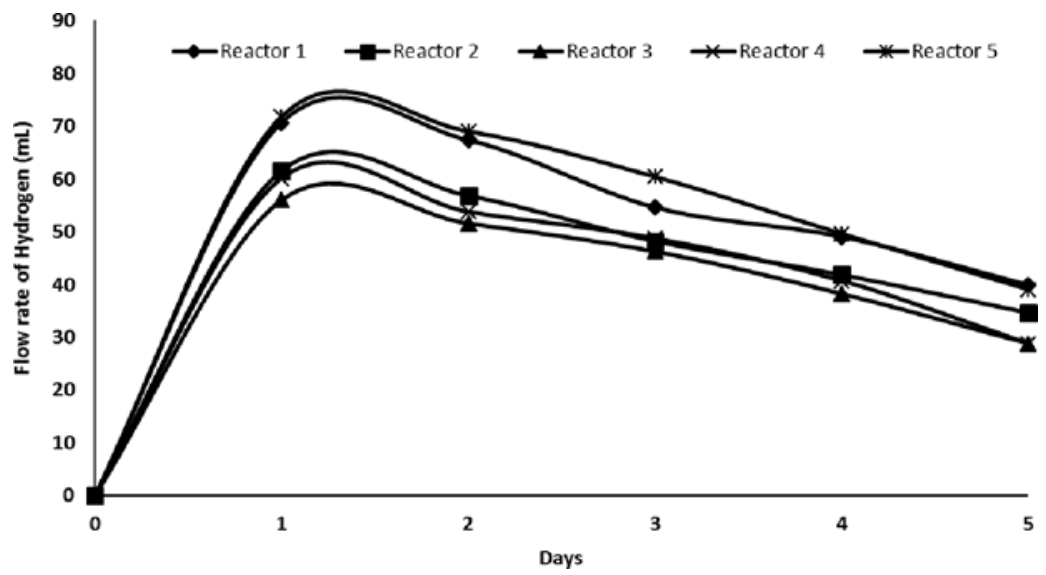

FIG. 3. FLOW RATE OF BIOHYDROGEN PRODUCTION FROM DIFFERENT RATIOS OF FW AND SS

\section{CONCLUSION}

In this study five batch tests were conducted to evaluate the potential of biohydrogen production at various volumetric ratios of FW and SS by anaerobic codigestion. The study is limited to the FW having high carbohydrates containing specially rice, which was added as more than $50 \%$ and was acidic in nature with the cumulative moisture content of $80-84 \%$. The SS used in the present study having only $3 \%$ of TS and was neutral in the nature. Moreover, the co-digestion was carried out at mesophilic temperature range of $35^{\circ} \mathrm{C}$. The maximum specific hydrogen yield106.7 $\mathrm{mL} / \mathrm{gVS}_{\text {added }}$ was obtained at a waste composition of 50:50 followed by $92.35 \mathrm{~mL} / \mathrm{gVS}_{\text {added }}$ from $90: 10$ of FW to SS.The results of this research demonstrate that FW and SS were suitable and useful for hydrogen production. Co-digestion of primary sludge and waste activated sludge with carbohydrate rich waste is an economically feasible approach for biological production of hydrogen on the basis of availability of the cheaper substrate. Biological production of hydrogen is also suitable for the treatment of FW and SS as it considerably decreases the organic matter present in the waste. Carbohydrate availability and $\mathrm{pH}$ are the principal factors impacting hydrogen generation. FW shows maximum hydrogen production due to larger availability of carbohydrate in it.On the other hand, the addition of SS with food waste enhance hydrogen production by providing $\mathrm{pH}$ buffering capacity to establish $\mathrm{pH}$. 
A pilot study may be carried out to check the feasibility of co-digestion of FW having high carbohydrates and SS and to carry out the energy balance of the system. Moreover, the energy used for heating and stirring may be obtained from the renewable sources of energy as solar and wind energies.

\section{ACKNOWLEDGEMENT}

The authors are wishingacknowledge to Mehran University of Engineering \& Technology, Jamshoro, Sindh, Pakistan, for its support to carry out this research work.

\section{REFERENCES}

[1] Momirlan, M., and Veziroglu, T., "Recent Directions of World Hydrogen Production”, Renewable and Sustainable Energy Review, Volume 3, pp. 219-23, 1999.

[2] Rifkin J., "The Hydrogen Economy: the Creation of the Worldwide Energy Web and the Redistribution of the Power on Earth”, Penguin Putnam, pp. 7-15, New York, NY, US, 2002.

Nicolaue, J.M., Dinsdale, R., and Guwy, A., "Hydrogen Production from Sewage Sludge Using Mixed Microflora Inoculums, Effects of pH and Enzymatic Pretreatment”, Bioresource Technology, Volume 99, pp. 6325-6331, 2008.

[4] Kadpan, I.K., and Kargi, F., "Bio-Hydrogen Production from Waste Materials”, Enzyme and Microbial Technology, Volume 38, pp. 569-582, 2006.

[6] Lee, D.Y., Ebie, Y., Xu, K.Q., Li, Y.Y., and Inamori, Y., "Continuous $\mathrm{H}_{2}$ and $\mathrm{CH}_{4}$ Production from High-Solid Food Waste in the Two-Stage Thermophilic Fermentation Process with the Recirculation of Digester Sludge", Bioresource Technology, Volume 101, pp.42-47, 2010.

[7] Benemann, J.R., "Hydrogen Biotechnology: Progress and Prospects", Nature Biotechnology, Volume 14, pp. 1101-1103, 1996.

[8] Hallenbeck, P.C., and Benemann, J.R., "Biological Hydrogen Production: Fundamentals and Limiting Processes”, International Journal of Hydrogen Energy, Volume 27, pp. 1185-1193, 2002.
Levin, D., Pitt, L., and Love, M., "Biohydrogen Production: Prospects and Limitations to Practical Application”, International Journal of Hydrogen Energy, Volume 29, No. 2, pp. 173-185, 2004.

[10] Ueno, Y., Kawai, T., Sato, S., Otsuka, S., and Morimoto, M., "Biological Production of Hydrogen from Cellulose by Natural Anaerobic Microflora”, Journal of Fermentation and Bioengineering, Volume 79, No. 4, pp. 395-397, 1995.

[11] Ghirardi, M.L., Zhang, L., Lee, J.W., Flynn, T., Seibert, M., and Greenbaum, E., "A Green Source of Renewable $\mathrm{H}_{2}$ ”, Tibtech, Volume 18, pp. 506-511, 2000.

[12] Melis, A., "Green Alga Hydrogen Production: Progress, Challenges and Prospects”, International Journal of Hydrogen Energy, Volume 27, pp. 1217-1228, 2002.

[13] Yokoi, H., Saitsu, A.S., Uchida, H., Hirose, J., Hayashi, S., and Takasaki, Y., "Microbial Hydrogen Production from Sweet Potato Starch Residue”, Journal of Bioscience Bioengineering, Volume 91, pp. 58-63, 2001.

[14] Hawkes, F.R., Dinsdale, R., Hawkes, D.I., and Hussy, I., "Sustainable Fermentative Hydrogen Production: Challenge for Process Optimization”, International Journal of Hydrogen Energy, Volume 27, pp. 1339-1347, 2002.

[15] Nandi, R., and Sengupta, S., "Microbial Production of Hydrogen: An Overview, Crit Rev Microbiol, Volume 24, No. 1, pp. 61-84, 1998.

[16] Das, D., and Veziroglu, T.N., "Hydrogen Production by Biological Processes: A Survey of Literature", International Journal of Hydrogen Energy, Volume 26, pp. 13-28, 2001.

[17] Zhu, H., andBeland, M., "Evaluation of Alternative Methods of Preparing Hydrogen Producing Seeds from Digested Wastewater Sludge”, International Journal of Hydrogen Energy, Volume 31, pp. 1980-1988, 2006.

[18] Noike, T., and Mizuno, O., "Hydrogen Fermentation of Organic Municipal Wastes”, Water Science Technology, Volume 42, No. 12, pp. 155-162, 2000.

[19] Mizuno, O., Ohara, T., Shinya, M., and Noike,T., "Characteristics of Hydrogen Production from Bean Curd Manufacturing Waste by Anaerobic Microflora”, Water Science Technology, Volume 42, Nos. 3-4, pp. 345-350, 2000.

[20] Noike, T., Takabatake, H., Mizuno, O., and Ohba, M., "Inhibition of Hydrogen Fermentation of Organic Wastes by Lactic Acid Bacteria”, International Journal of Hydrogen Energy, Volume 27, pp. 1367-1371, 2002. 
[21] Wang, C.C., Chang, C.W., Chu, C.P., Lee, D.J., Chang, B.-.V., Liao, C.S., and Tay, J.H., "Using Filtrate of Waste Biosolids to Effectively Produce Bio-Hydrogen by Anaerobic Fermentation”, Water Resource, Volume 37, pp. 2789-2793, 2003.

[22] Wang, C.C., Chang, C.W., Chu, C.P., Lee, D.J., Chang, B.-.V., and Liao, C.S., "Producing Hydrogen from Wastewater Sludge by Clostridium Bifermentans”, Journal of Biotechnology, Volume 102, pp. 83-92, 2003.

[23] Okamoto, M., Miyahara, T., Minuno, O., and Noike, T., "Biological Hydrogen Potential of Materials Characteristic of the Organic Fraction of Municipal Solids Wastes”, Water Science Technology, Volume 41, No. 3, pp. 25-32, 2000

[24] Lay, J.J., Fan, K.S., Chang, J.l., and Ku, C.H., "Influence of Chemical Nature of Organic Wastes on Their Conversion to Hydrogen by Heat-Shock Digested Sludge”, International Journal of Hydrogen Energy, Volume 28, pp. 1361-1367, 2003

[25] Lay, J.J., Lee, Y.J., and Noike, T., "Feasibility of Biological Hydrogen Production from Organic Fraction of Municipal Solid Waste”, Water Resource, Volume 33, No. 11, pp. 2579-2586, 1999.

[26] Han, S.K., and Shin, H.S., "Enhanced Acidogenic Fermentation of Food Waste in a Continuous-Flow Reactor”, Waste Management Resources, Volume 20, pp. 110-118, 2002

[27] Kubaska, M., Sedlacek, S., Bodik, I., and Kissova, B., "Food Waste as Biodegradable Substrates for Biogas Production", Proceedings of $37^{\text {th }}$ International Conference of Slovak Society of Chemical Engineering, pp.1413-1418, TatranskeMatliare, Slovakia 2010.

[28] Kim, S.H., Han, S.K., Shin H.S., "Feasibility of Biohydrogen Production by Anaerobic Co-Digestion of Food Waste and Sewage Sludge”, International Journal of Hydrogen Energy, Volume 29, pp. 1607-1616, 2004.

[29] Zhu, H., Parker,W., Basnar, R., Proracki,A., Falleta, P., Beland, M., and Seto, P., "Biohydrogen Production by Anaerobic Co-Digestion of Municipal Food Waste and Sewage Sludges”, International Journal of Hydrogen Energy, Volume 33, pp. 3651-3659, 2008.

[30] Mizuno, O., Dinsdale, R., Hawkes, F.R., Hawkes, D., and Noike, T., "Enhancement of Hydrogen Production from Glucose by Nitrogen Gas Sparging”, Bioresource Technology, Volume 73, pp. 59-65, 2000.

[31] Shin, H.S., Youn, J.H., and Kim, S.H., "Hydrogen Production from Food Waste in Anaerobic Mesophilic and ThermophilicAcidogenesis”, International Journal of Hydrogen Energy, Volume 29, pp. 1355-1363, 2004.
Chen, C.C., and Lin, C.Y., “Using Sewage Sludge as Seed in an Anaerobic Hydrogen Producing Reactor", Proceedings $25^{\text {th }}$ Conference on Wastewater Treatment Technology, pp. 368-372, Yun-Lin Taiwan, 1-2 December, 2000.

[33] Tanisho, S., and Ishiwata, Y., "Continuous Hydrogen Production from Molasses by Bacterium EnterobacterAerogene", International Journal of Hydrogen Energy, Volume 19, pp. 807-812, 1994.

[34] Wang, C.C., Chang, C.W., Chu, C.P., Lee, D.J., Chang, B.V., and Liao, C.S., "Efficient Production of Hydrogen from Wastewater Sludge”, Journal of Chemical Technology and Biotechnology, Volume 79, pp. 426-427, 2004.

[35] Lin, C.Y., and Chang, R.C, "Hydrogen Production during the Anaerobic Acidogenic Conversion of Glucose”, Journal of Chemical Technology and Biotechnology, Volume 74, No. 6, pp. 498-500, 1999.

[36] Tao, Y., Chen, Y., Wu, Y., Hu, Y., and Zheu, Z., “High Hydrogen Yield from a Two Step Process of Dark and Photo-Fermentation of Sucrose”, International Journal of Hydrogen Energy, Volume 32, pp. 200-206, 2007.

[37] Liu, H., Zhang, T., and Fang, H.P.P., “Thermophilic $\mathrm{H}_{2}$ Production from Cellulose Containing Wastewater”, Biotechnol Letters, Volume 25, pp. 365-369, 2003.

[38] Lay, J.J., "Biohydrogen Generation by Mesophilic Anaerobic Fermentation of Microcrystalline Cellulose", Biotechnology and Bioengineering, Volume 74, pp. 281-287, 2001.

[39] Chen, C.C., and Lin, C.Y., "Using Sucrose as a Substrate in an Anaerobic Hydrogen Producing Reactor", Advance Environmental Resources, Volume 7, pp. 695-699, 2003.

[40] Chen, C.C., Lin, C.Y., and Chang, J.S., "Kinetics of Hydrogen Production with Continuous Anaerobic Cultures Utilizing Sucrose as Limiting Substrate”, Applied Microbiology and Biotechnology, Volume 57, pp. 56-64, 2001.

[41] Chang, F.Y., and Lin, C.Y., "Biohydrogen Production Using an Up-Flow Anaerobic Sludge Blanket Reactor”, International Journal Hydrogen Energy, Volume 29, pp. 33-39, 2004.

[42] Owen, W.F., Stuckey, D.C., Healy J.J., Young, L.Y., and McCarty, P.L., "Bioassay for Monitoring Biochemical Methane Potential and Anaerobic Toxicity”, Water Resources, Volume 13, pp. 485-493, 1979.

[43] APHA, "Standard Methods for the Examination of Water and Wastewater", $20^{\text {th }}$ Edition, American Public Health Associaion, Washington, DC, 1998. 